Jurnal Media Agribisnis Vol. 2 No. 2 Tahun 2017 Hal 45 - 59

Media Komunikasi Hasil Penelitian Bidang Ilmu Agribisnis

ISSN print 2548-7027

ISSN online 2541-6898

\title{
EFISIENSI ALOKATIF FAKTOR-FAKTOR PRODUKSI DAN PENDAPATAN USAHATANI PADI (Oryza sativa L.) (Studi Kasus Di Desa Simpang Datuk Kecamatan Nipah Panjang Kabupaten Tanjung JabungTimur)
}

\author{
Asmaida \\ Program Studi Agribisnis, Fakultas Pertanian Universitas Batanghari \\ Jl. Slamet Riyadi-Broni, Jambi. 36122. Telp. +6274160103 \\ email : asmaida.syandri@yahoo.co.id
}

\begin{abstract}
The research was conducted in "Simpang Datuk" Village, "Nipah Panjang" Sub-district, "Tanjung Jabung Timur" Regency, with several aims e.g: to analyze the income of rice farmers, Analyzing the effect of production factors in rice farming, Analyzing the allocative efficiency of useness on the production factors that influenced the rice production. This location was selected by considering that it was the rice production centre. Survey method was used in this research, and the collected data (both primary and secondary) had acros section type. There were 39 households as a samples from a total 259 farmers population which taken by simple random sampling method. The description analysis and Cobb Douglas production function were applied in this research. The results showed: (1) the total average of farmers income was Rp.27.507.997,-/period/Ha, the total cost average was Rp.8.630.942,-/period/Ha and the earnings average was Rp.18.877.055,-/period/Ha. R/C ratio was 3.19. This indicates that the rice farming was quite profitable, because the $R / C$ value was more than 1. The production factors that showed significant effect toward to the farming activities were seed and fertilizer, The Result of analysis on allocative efficiency of production factors useness on rice farming showed that useness allocation of seed and fertilizer was 24,65 $\mathrm{kg}$ and as 7,650 $\mathrm{kg}$ respectively. The result of these useness allocation both seed and fertilizer were more than 1, so it showed an unefficiently allocation.
\end{abstract}

Keywords: Farming, Rice, Income, Production Function, Efficiency

\begin{abstract}
Abstrak
Penelitian dilaksanakan di Desa Simpang Datuk Kecamatan Nipah Panjang Kabupaten Tanjung Jabung Timur, dengan tujuan untuk menganalisis pendapatan petani padi, faktor produksi yang berpengaruh dalam usahatani padi, dan efisiensi alokatif penggunaan faktor produksi yang berpengaruh terhadap produksi padi. Metode penelitian menggunakan metode survey, data yang dikumpulkan meliputi data primer dan data sekunder dengan jenis data cros section. Sampel penelitian sebanyak 39 RTP dari total populasi 259 RTP yang diambil secara simple random sampling. Metode analisis yang digunakan yaitu analisis data kualitatif dan data kuantitatif dengan perhitungan pendapatan petani dan fungsi produksi Cobb Douglas. Hasil penelitian : Rata-rata total penerimaan petani padi Rp.27.507.997,-/MT/Ha, rata-rata total biaya Rp.8.630.942,-/MT/Ha dan rata-rata pendapatan Rp.18.877.055,-/MT/Ha. Nilai $\mathrm{R} / \mathrm{C}$ rasio sebesar 3,19. Hal ini menunjukkan bahwa rata-rata usahatani padi di daerah penelitian cukup menguntungkan, karena nilai RC rasionya lebih dari 1 . Faktor-faktor produksi yang berpengaruh dalam kegiatan usahatani padi adalah faktor produksi benih dan pupuk. Hasil analisis efisiensi alokatif penggunaan faktor produksi benih sebesar $24,65 \mathrm{~kg}$ dan pupuk sebesar 7,650 kg, hasil penggunaan benih dan pupuk tersebut keduanya lebih dari 1 , sehingga belum efisien secara alokatif.
\end{abstract}

Kata kunci: Usahatani, Padi, Pendapatan, Efisiensi, Fungsi Produksi 
Jurnal Media Agribisnis Vol. 2 No. 2 Tahun 2017 Hal 45 - 59

Media Komunikasi Hasil Penelitian Bidang Ilmu Agribisnis

ISSN print 2548-7027

ISSN online 2541-6898

\section{PENDAHULUAN}

Padi merupakan tanaman utama pangan yang menghasilkan beras sebagai sumber makanan pokok sebagian besar penduduk Indonesia. Tanaman padi ini merupakan tanaman pangan yang banyak dibudidayakan oleh petani di Indonesia. Namun pada saat ini produksi padi belum stabil menopang kebutuhan besar nasional yang terus meningkat. Hal ini terindikasi dari volume dan nilai impor beras yang masih tinggi. Penyebab Indonesia melakukan impor beras, disebabkan oleh lahan yang semakin sempit akibat dari ahli fungsi lahan dan akibat pengaruh era globalisasi. Dalam hal ini intensifikasi pertanian perlu dilakukan, karena intensifikasi tersebut merupakan pengolahan lahan pertanian yang ada dengan sebaik-baiknya untuk meningkatkan hasil pertanian khususnya padi dengan menggunakan berbagai sarana.

Desa Simpang Datuk adalah desa yang memiliki luas lahan dan produksi padi yang tertinggi dibandingkan dengan desa-desa lainnya yang ada di Kecamatan Nipah Panjang Kabupaten Tajung Jabung Timur serta produktifitasnya berada diatas rata-rata produktifitas padi Kecamatan Nipah Panjang, lebih jelasnya dapat dilihat pada Tabel 1.

Tabel 1. Luas Lahan, Produksi dan Produktivitas Padi per Desa di Kecamatan Nipah Panjang Tahun 2014

\begin{tabular}{clccc}
\hline No & \multicolumn{1}{c}{ Desa/ Kelurahan } & $\begin{array}{c}\text { Luas Lahan } \\
(\mathrm{Ha})\end{array}$ & $\begin{array}{c}\text { Produksi } \\
(\text { Ton })\end{array}$ & $\begin{array}{c}\text { Produktivitas } \\
(\text { Ton/Ha })\end{array}$ \\
\hline 1 & Desa Sungai Raya & 893 & $2.659,425$ & 2,978 \\
2 & Desa Teluk Kijing & 473 & $1.720,560$ & 3,638 \\
3 & Desa Pamusiran & 381 & $1.205,406$ & 3,164 \\
4 & Kel. Nipah Panjang I & 589 & $2.268,014$ & 3,851 \\
5 & Kel. Nipah Panjang II & 497 & $1.602,823$ & 3,225 \\
$\mathbf{6}$ & Desa Simpang Datuk & $\mathbf{1 . 0 3 6}$ & $\mathbf{3 . 8 4 9 , 8 3 6}$ & $\mathbf{3 , 7 1 6}$ \\
7 & Desa Simpang Jelita & 313 & $1.222,538$ & 3,906 \\
8 & Desa Bunga Tanjung & 1.016 & $3.280,917$ & 3,229 \\
9 & Desa Sungai Tering & 545 & $1.800,300$ & 3,303 \\
10 & Desa Sungai Jeruk & 784 & $2.753,181$ & 3,512 \\
\hline & Jumlah & 6.527 & $22.363,000$ & \\
& Rata-rata & 652,7 & $2.236,3$ & 3,43 \\
\hline
\end{tabular}

Sumber : BP3K Kecamatan Nipah Panjang, 2015

Berdasarkan uraian di atas, sehingga menjadikan Desa Simpang Datuk menjadi daerah lumbung padi dan sentra produksi padi di Kecamatan Nipah Panjang. Selanjutnya juga menggambarkan bahwa usahatani padi di daerah tersebut memiliki potensi yang cukup besar apabila dikelola dengan baik. Kegiatan usahatani memiliki tujuan meningkatkan produktivitas agar keuntungan menjadi lebih tinggi. Produksi dan produktivitas tidak lepas dari faktor-faktor produksi yang dimiliki petani untuk meningkatkan produksi hasil panennya.

Faktor produksi yang dimiliki petani umumnya memiliki jumlah yang terbatas tetapi disisi lain petani juga ingin meningkatkan produksi usahataninya. Hal tersebut menuntut petani untuk menggunakan faktor-faktor produksi yang dimiliki dalam pengelolaan usahatani secara efesien. Salah satu cara yang dapat digunakan untuk mengetahui penggunaan faktor produksi usahatani padi secara efesien yaitu dengan menghitung efesiensi secara alokatif. Efesiensi alokatif menunjukan hubungan antara biaya dan ouput, dimana efesiensi alokatif tercapai apabila petani mampu 
Jurnal Media Agribisnis Vol. 2 No. 2 Tahun 2017 Hal 45 - 59

Media Komunikasi Hasil Penelitian Bidang Ilmu Agribisnis

ISSN print 2548-7027

ISSN online 2541-6898

memaksimalkan keuntungan yaitu menyamakan nilai produk marjinal setiap faktor produksi dengan harganya. Dengan mengetahui penggunaan faktor-faktor produksi yang optimal maka dapat tercapai keuntungan maksimal dengan penggunaan biaya sekecilkecilnya. Pencapaian efesiensi secara alokatif dapat dilakukan apabila petani telah mengetahui faktor produksi apa yang berpengaruh pada usahatani padi. Berdasarkan uraian tersebut di atas, maka penulis tertarik untuk melakukan penelitian dengan permasalahan yang akan di bahas dalam penelitian ini yaitu mengenai pendapatan petani padi, faktor produksi yang berpengaruh pada usahatani padi dan efisiensi alokatif penggunaan faktor produksi yang berpengaruh terhadap produksi padi.

\section{METODOLOGI PENELITIAN}

Penelitian dilaksanakan di Desa Simpang Datuk Kecamamatan Nipah Panjang Kabupaten Tanjung Jabung Timur. Metode penelitian menggunakan metode survei. Petani adalah sebagai sumber data primer, dengan tehnik pengumpulan data secara observasi dan wawancara dengan menggunakan kuisioner. Data sekunder adalah data yang diperoleh atau dikumpulkan oleh pihak lain, dapat bersumber dari pustaka dan lembaga yang terkait dengan penelitian ini.

Dalam pengumpulan data penelitian dilakukan penarikan sampel. Metode penentuan sampel menggunakan metode Simple Random Sampling. Responden yang dipilih yaitu petani yang lokasi usahanya berada di Desa Simpang Datuk Kecamatan Nipah Panjang, dengan jumlah petani padi (populasi) sebanyak 259 RTP. Jumlah besarnya sampel adalah sebanyak 39 responden yang dihitung berdasarkan rumus (Umar. H, 2003) :

$$
n=\frac{N}{1+N\left(e^{2}\right)}
$$

Keterangan : $\mathrm{N}=$ Jumlah populasi

$\mathrm{n}=$ Jumlah sampel

$\mathrm{e}=$ Kesalahan pengambilan sampel ditetapkan sebesar $15 \%$

Pada penelitian sosial persentase kesalahan yang bisa ditolelir berkisar 5\%-20\% karena pada hasil penelitian sosial sulit dipastikan keakuratan data seperti pada penelitian ilmu pasti.

Data penelitian dianalisis menggunakan metode deskriptif kualitatif-kuantitatif dan interperensi untuk menjawab perumusan masalah, yang terdiri dari analisis pendapatan, analisis faktor produksi yang berpengaruh pada usahatani padi dan analisis efisiensi alokatif penggunaan faktor produksi yang berpengaruh terhadap produksi padi, dengan uraian sebagai berikut :

\section{Analisis Pendapatan}

a. Biaya

Untuk menganalisis biaya yang dikeluarkan dalam usahatani padi dapat dihitung dengan menggunakan rumus (Soekartawi, 2003): $\quad \mathrm{TC}=\mathrm{TFC}+\mathrm{TVC}$

Dimana $: \mathrm{TC}=$ Total Cost $($ total biaya $)(\mathrm{Rp} / \mathrm{MT})$

$\mathrm{TFC}=$ Fix Cost (biaya tetap) $(\mathrm{Rp} / \mathrm{MT})$

$\mathrm{TVC}=$ Variable Cost $($ biaya variabel $)(\mathrm{Rp} / \mathrm{MT})$

\section{b. Penerimaan}

Untuk menganalisis penerimaan yang diterima petani padi dihitung dengan menggunakan rumus (Soekartawi, 2003) : $\quad \mathrm{TR}=\mathrm{Y}$ x Py

Dimana: $\mathrm{TR}=$ Total Revenue atau penerimaan total $(\mathrm{Rp} / \mathrm{MT})$

$\mathrm{Y}=$ Jumlah Produk yang dihasilkan (Kg/MT)

Py $=$ Harga jual produk $(\mathrm{Rp} / \mathrm{Kg})$ 
Jurnal Media Agribisnis Vol. 2 No. 2 Tahun 2017 Hal 45 - 59

Media Komunikasi Hasil Penelitian Bidang Ilmu Agribisnis

ISSN print 2548-7027

ISSN online 2541-6898

\section{c. Pendapatan}

Untuk menganalisis pendapatan yang diterima petani padi dihitung dengan menggunakan rumus (Soekartawi, 2003) : $\pi=\mathrm{TR}-\mathrm{TC}$

Dimana: $\pi \quad=$ Pendapatan usahatani padi (Rp/MT)

$\mathrm{TR}=$ Total Revenue atau Total Penerimaan $(\mathrm{Rp} / \mathrm{MT})$

$\mathrm{TC}=$ Total Cost atau Total Biaya $(\mathrm{Rp} / \mathrm{MT})$

\section{d, Revenue Cost Ratio (RC Ratio)}

Untuk mengetahui tingkat pengelolaan usaha atau tingkat efesiensi ekonomi dari usaha, dilakukan analisis dengan menggunakan kriteria revenue cost of rasio ( $\mathrm{RC}$ ratio). $\mathrm{RC}$ ratio adalah peerbandingan antara penerimaan atau pendapatan kotor dengan biaya total yang dikeluarkan dengan rumus (Kadariah, 1978) :

RC Ratio $=\frac{\text { Penerimaan }(T R)}{\text { Biayaproduksi }(T C)}$

Dengan kriterianya adalah sebagai berikut :

- RC Ratio > 1 berarti usahatani menguntungkan dan layak untuk dijalankan

- RC Ratio $=1$ berarti usahatani tidak rugi atau tidak untung dan perlu dipertimbangkan

- RC Ratio < 1 berarti usahatani tidak menguntungkan dan tidak layak untuk dijalankan.

\section{Analisis Faktor-faktor Produksi Usahatani Padi}

Untuk mengetahui pengaruh penggunaan faktor produksi digunakan analisis fungsi produksi Cobb Douglas Soekartawi (1994) dengan menggunakan program software SPSS. secara matematik, fungsi Cobb-Douglas dapat dinyatakan sebagai berikut :

$$
Y=a X_{1}^{b 1} X_{2}^{b 2} \ldots X_{i}^{b i} \ldots X_{n}^{b n} e^{n}
$$

Bila fungsi Cobb-Douglas tersebut dinyatakan oleh hubungan $\mathrm{Y}$ dan $\mathrm{X}$, maka:

$\mathbf{Y}=\mathbf{f}\left(\mathbf{X}_{1}, \mathbf{X}_{2}, \ldots, \mathbf{X}_{1}, \ldots, \mathbf{X}_{\mathbf{n}}\right)$

Dimana : $\mathrm{Y}=$ variabel yang dijelaskan

$\mathrm{X}=$ variabel yang menjelaskan

$\mathrm{a}, \mathrm{b}=$ besaran yang akan diduga

$\mathrm{e} \quad=$ logaritma natural, $\mathrm{e}=2,718$

Untuk memudahkan pendugaan terhadap persamaan tersebut, maka persamaan ini diubah menjadi bentuk linear berganda dengan cara melogaritmakan persamaan tersebut.

\section{$\operatorname{LnY}=\operatorname{In} a+b_{1} \operatorname{Ln} X_{1}+b_{2} \operatorname{Ln} X_{2}+b_{3} \operatorname{Ln} X_{3}+b_{4} \operatorname{Ln} X_{4}+u^{e}$}

Dimana : $\mathrm{Y}=$ Jumlah produksi padi yang dihasilkan dalam satu kali masa tanam $(\mathrm{kg})$

$\mathrm{X}_{1}=$ Jumlah benih yang digunakan dalam satu kali masa tanam $(\mathrm{kg})$

$\mathrm{X}_{2}=$ Jumlah seluruh pupuk yang digunakan dalam satu kali masa tanam $(\mathrm{kg})$

$\mathrm{X}_{3}=$ Jumlah seluruh pestisida yang digunakan dalam satu kali masa tanam (ltr)

$\mathrm{X}_{4}=$ Jumlah tenaga kerja yang digunakan dalam satu kali masa tanam (HOK)

$\mathrm{a}, \mathrm{b}=$ Besaran yang akan diduga

$\mathrm{u} \quad=$ kesalahan (disturbance term)

Adanya perbedaan dalam satuan dan besaran variabel bebas maka persamaan regresi ini harus dibuat dengan model logaritma natural. Alasan pemilihan logartima natural menurut (Ghozali, 2008) adalah untuk (1) menghindari adanya heterokesdatisitas, (2) mengetahui koefisien yang menunjukkan elastisitas dan (3) mendekatkan skala data. Sebelum dilakukan estimasi model regresi berganda, data yang digunakan harus dipastikan terbebas dari penyimpangan asumsi klasik untuk multikolinearitas, heteroskesdasitas, dan autokorelasi (Gujarati, 2003). Uji klasik ini dapat dikatakan sebagai kriteria ekonometrika 
Jurnal Media Agribisnis Vol. 2 No. 2 Tahun 2017 Hal 45 - 59

Media Komunikasi Hasil Penelitian Bidang Ilmu Agribisnis

ISSN print 2548-7027

ISSN online 2541-6898

untuk melihat apakah hasil estimasi memenuhi dasar linear klasik atau tidak. Dengan terpenuhinya asumsi-asumsi klasik ini maka estimator OLS dari koefisien regresi adalah penaksir tak bias linear terbaik BLUE (Best Linear Unbiased Estimator) dalam Gujarati (2003), agar tahap estimasi yang diperoleh benar dan efektif. Salah satu asumsi yang harus dipenuhi untuk memenuhi sifat BLUE adalah homoskedastisitas, bila asumsi tersebut tidak terpenuhi maka yang terjadi adalah sebaliknya, yakni heteroskedastisitas yang artinya variansi error tidak konstan. Variansi error yang tidak konstan ini menyebabkan kesimpulan yang dicapai tidak valid atau bias. Setelah data dipastikan bebas dari penyimpangan asumsi klasik, maka dilanjutkan dengan uji hipotesis kemudian dilakukan uji efisiensi sehingga tujuan penelitian yang ketiga dapat terjawab, yaitu menghitung tingkat efisiensi penggunaan faktor produksi pada usahatani padi.

\section{A. Uji Asumsi Klasik}

Persamaan yang diperoleh dari sebuah estimasi dapat dioperasikan secara statistik jika memenuhi asumsi klasik, yaitu memenuhi asumsi bebas multikolinearitas, heteroskedastisitas, dan normalitas. Pengujian asumsi klasik ini dilakukan dengan bantuan software analisis data kualitatif.

\section{a). Uji Multikolinearitas}

Multikolinearitas menandakan bahwa terdapat hubungan linear (korelasi) yang sempurna atau pasti, diantara beberapa atau semua variabel yang menjelaskan dari model regresi (Gujarati, 2003). Model regresi yang baik seharusnya tidak terjadi hubungan linear diantara variabel independen. Menurut Ghozali (2005), bahwa untuk mendeteksi ada tidaknya multikolinearitas didalam model regresi adalah sebagai berikut :

- Menganalisis matrik korelasi variabel-variabel independen. Jika antar variabel independen ada korelasi yang cukup tinggi (umumnya di atas 0,90), maka hal ini merupakan indikasi adanya multikolinearitas.

- Multikolinearitas dapat juga dilihat dari (1) nilai tolerance dan lawannya (2) Variance Inflation Factor (VIF). Kedua ukuran ini menunjukkan setiap variabel independen manakah yang dijelaskan oleh variabel independen lainnya. Dalam pengertian sederhana setiap variabel independen menjadi variabel dependen dan diregresikan terhadap variabel independen lainnya. Tolerance mengukur variabilitas variabel independen lainnya. Jadi nilai tolerance yang rendah sama dengan nilai VIF yang tinggi (karena $\mathrm{VIF}=1 /$ nilai tolerance). Nilai cut off yang umum dipakai untuk menunjukkan adanya multikolinearitas adalah nilai tolerance $<0,10$ atau sama dengan nilai $\mathrm{VIF} \leq 10$.

\section{b). Uji Heteroskedastisitas}

Uji heteroskedastisitas digunakan untuk menguji apakah dalam suatu model regresi terjadi ketidaksamaan variance dan residual dari satu pengamatan ke pengamatan yang lain. Jika variance dari residual satu pengamatan ke pengamatan lain tetap, maka disebut homoskedastisitas dan jika berbeda maka disebut heteroskedastisitas (Ghozali, 2008). Adapun cara untuk mendeteksi ada atau tidaknya heteroskedastisitas menurut Ghozali (2008), yaitu dengan melihat grafik scatterplot antara nilai prediksi variabel dependen yaitu ZPRED dengan residualnya SRESID. Deteksi ada tidaknya heteroskedastisitas dapat dilakukan dengan melihat ada tidaknya pola tertentu pada grafik scatterplot dimana sumbu $\mathrm{Y}$ adalah $\mathrm{Y}$ yang telah diprediksi, dan sumbu $\mathrm{X}$ adalah residual (Y prediksi - Y sesungguhnya). Adapun dasar pengambilan keputusan dilakukan dengan dasar analisis sebagai berikut : 
Jurnal Media Agribisnis Vol. 2 No. 2 Tahun 2017 Hal 45 - 59

Media Komunikasi Hasil Penelitian Bidang Ilmu Agribisnis

ISSN print 2548-7027

ISSN online 2541-6898

- Jika ada pola tertentu, seperti titik-titik yang ada membentuk pola yang teratur (bergelombang, melebar, menyempit), mengindikasikan telah terjadi heteroskedastisitas.

- Jika tidak ada pola yang jelas, serta titik-titik menyebar diatas dan dibawah angka 0 pada sumbu Y, maka tidak terjadi heteroskedastisitas.

\section{c). Uji Asumsi Normalitas}

Uji asumsi normalitas digunakan untuk menguji apakah dalam suatu model regresi, variabel dependen atau keduanya mempunyai distribusi normal atau mendekati normal (Santoso, 2000). Apabila asumsi ini tidak terpenuhi, baik uji $\mathrm{F}$ ataupun uji-t, dan nilai estimasi nilai variabel dependen menjadi tidak valid (Utomo, 2007). Untuk mendekati normalitas pada model regresi yaitu dengan melihat penyebaran data (titik) pada sumbu diagonal dari grafik normal. Adapun dasar pengambilan keputusannya berdasarkan kriteria uji :

- Jika data menyebar di sekitar garis diagonal dan mengikuti arah garis diagonal, maka model regresi memenuhi asumsi normalitas.

- Jika data menyebar jauh dari garis diagonal dan tidak mengikuti arah garis diagonal, maka model regresi tidak memenuhi asumsi normalitas.

\section{d). Uji Autokorelasi}

Uji autokorelasi adalah salah satu bagian dari uji asumsi klasik dimana suatu persamaan regresi dikatakan telah memenuhi asumsi tidak terjadi autokorelasi dengan menggunakan uji Durbin Watson. Menurut Santoso (2000) bahwa tujuan uji autokorelasi adalah untuk mengetahui apakah dalam suatu model regersi linear ada korelasi antara kesalahan pengganggu dengan kesalahan sebelumnya. Apabila hal ini terjadi maka terdapat masakah autokorelasi. Adapun kritik pengujiannya adalah jika $d u<d<4$-du maka Ho ditolak yang berarti tidak ada autokorelasi baik positif maupun negatif. Untuk mengetahui ketepatan model regresi sampel dalam menaksir nilai aktualnya dapat diukur dari goodness of fit- nya. Goodness of fit dalam model regresi dapat diukur dari nilai koefisien determinasi, nilai statistik F, dan uji statistik t.

\section{B. Pengujian Hipotesis}

\section{a) Pengujian secara serentak (Uji F)}

Uji statistik F pada dasarnya menunjukkan apakah semua variabel independen atau bebas yang dimasukkan dalam model mempunyai pengaruh secara bersama-sama terhadap variabel dependen (Ghozali, 2008). Pengujian F ini dilakukan dengan membandingkan nilai $\mathrm{F}$ hasil perhitungan dengan $\mathrm{F}$ tabel, maka kita menerima hipotesis alternatif yang menyatakan bahwa semua variabel independen secara serentak dan signifikan mempengaruhi variabel dependen dengan langkah-langkah pengujian sebagai berikut :

\section{Membuat formulasi hipotesis}

$\mathrm{H}_{0}: \mathrm{b} 1=\mathrm{b} 2=\mathrm{b} 3=\mathrm{b} 4=\mathrm{b} 5=0$; Tidak ada pengaruh yang signifikan dari variabel independen (X) secara bersama-sama terhadap variabel dependen $(\mathrm{Y})$

$\mathrm{Ha}: \mathrm{b} 1 \neq \mathrm{b} 2 \neq \mathrm{b} 3 \neq \mathrm{b} 4 \neq \mathrm{b} 5 \neq 0$; Ada pengaruh yang signifikan dari variabel independen (x) secara bersama-sama terhadap variabel dependen (y).

\section{Menentukan level signifikansi dengan nilai tabel F-tabel}

3. Mencari F-hitung dengan rumus : $\quad F_{\text {hitung }}=\frac{R^{2} /(k-1)}{\left(1-R^{2}\right) /(n-k)}$

4. Mengambil keputusan : - Jika F-hitung $\leq$ F-tabel, maka $\mathrm{H}_{0}$ diterima atau $\mathrm{H}_{\mathrm{a}}$ ditolak - Jika F-hitung > F-tabel, maka $\mathrm{H}_{0}$ ditolak atau $\mathrm{H}_{\mathrm{a}}$ diterima 
Jurnal Media Agribisnis Vol. 2 No. 2 Tahun 2017 Hal 45 - 59

Media Komunikasi Hasil Penelitian Bidang Ilmu Agribisnis

ISSN print 2548-7027

ISSN online 2541-6898

\section{b) Koefisien Determinasi $\left(\mathbf{R}^{2}\right)$}

Dalam suatu penelitian yang bersifat observasi, perlu diperhatikan seberapa jauh model yang terbentuk dapat menerangkan kondisi yang sebenarnya. Dalam analisis regresi dikenal dengan koefisien determinasi $\left(\mathrm{R}^{2}\right)$. Nilai koefisien determinasi ini merupakan suatu ukuran yang menunjukkan besar sumbangan dari variabel independen terhadap variabel dependen, atau dengan kata lain koefisien determinasi menunjukkan variasi turunnya $\mathrm{Y}$ yang diterangkan oleh pengaruh linear X. Apabila nilai koefisien determinasi yang diberi simbol $\mathrm{R}^{2}$ ini mendekati angka 1 , maka variabel independen semakin mendekati hubungan dengan variabel dependen sehingga dapat dikatakan bahwa penggunaan model tersebut dapat dibenarkan (Gujarati, 1997). Adapun kegunaan koefisien determinasi adalah :

- Sebagai ukuran ketetapan garis regresi yang dibuat dari hasil estimasi terhadap sekelompok data hasil observasi. Semakin besar nilai $\mathrm{R}^{2}$, maka semakin bagus garis regresi yang terbentuk, dan semakin kecil $\mathrm{R}^{2}$, maka semakin tidak tepat garis regresi tersebut yang mewakili dari hasil observasi.

- Untuk mengukur proporsi (persentase) dari jumlah variasi Y yang diterangkan oleh model regresi atau untuk mengukur besar sumbangan dari variabel $\mathrm{X}$ terhadap variabel $\mathrm{Y}$.

\section{c). Uji Individual (uji t)}

Menurut Ghozali (2005), uji t pada dasarnya untuk menunjukkan seberapa jauh pengaruh satu variabel bebas secara individual dalam menerangkan variasi variabel dependen. Pengujian uji t bertujuan unruk mengetahui signifikasi atau tidak nya koefisien regresi atau agar dapat diketahui variabel independen $(\mathrm{x})$ yang berpengaruh signifikan terhadap variabel independen (y) secara parsial. Adapun langkah-langkah pengujian hipotesis adalah sebagai berikut :

\section{1). Membuat formulasi hipotesis}

$\mathrm{H}_{0}: \mathrm{b}_{1} \leq 0$, Diduga variabel bebas tidak mempunyai pengaruh tehadap variabel terikat.

$\mathrm{H}_{1}: \mathrm{b}_{1}>0$, Diduga variabel bebas mempunyai pengaruh terhadap variabel terikat.

2). Menentukan level signifikansi dengan menggunakan $t$ - tabel

3). Menghitung nilai $t$ - Statistik dengan rumus : $t=\frac{b i}{s b i}$

Dimana : $\mathrm{t}=\mathrm{t}_{\text {hitung }}$

$b_{i}=$ koefisien regresi dari variabel ke- $i$

$\mathrm{Sb}_{\mathrm{i}}=$ standar error perkiraan ke- $\mathrm{b}_{\mathrm{i}}$

4). Mengambil keputusan : - Jika t-hitung $\leq \mathrm{t}$-tabel, maka $\mathrm{H}_{0}$ diterima atau $\mathrm{H}_{\mathrm{a}}$ ditolak

- Jika t-hitung > t-tabel, maka $\mathrm{H}_{0}$ ditolak atau $\mathrm{H}_{\mathrm{a}}$ diterima

Dalam menerima dan menolak hipotesis yang diajukan denga melihat hasil output SPSS, apabila nilai signifikan $<0,05$, maka disimpulkan bahwa $\mathrm{H}_{0}$ ditolak dan $\mathrm{H}_{\mathrm{a}}$ diterima (Ghozali, 2008).

\section{Analisis Efisiensi Alokatif Penggunaan Faktor-Faktor Produksi}

Uji efisiensi digunakan untuk melihat apakah input atau faktor produksi yang digunakan pada usahatani padi sudah efisien atau belum. Efisiensi yang digunakan dalam penelitian ini adalah efisiensi alokatif (harga). Efisiensi adalah upaya penggunaan input sekecil-kecilnya mendapatkan produksi yang sebesar-besarnya. Efisiensi harga tercapai apabila perbandingan antara nilai produktifitas marjinal $\left(\mathrm{NPM}_{\mathrm{x}}\right)$ sama dengan biaya input tersebut (Px), secara matematis dapat dituliskan sebagi berikut (Soekartawi, 1986) :

$$
\mathrm{NPM}_{\mathrm{x}}=\mathrm{Px} \text { atau } \frac{N P M x}{P x}=1
$$


Jurnal Media Agribisnis Vol. 2 No. 2 Tahun 2017 Hal 45 - 59

Media Komunikasi Hasil Penelitian Bidang Ilmu Agribisnis

ISSN print 2548-7027

ISSN online 2541-6898

$$
\frac{b Y P_{y}}{X}=P_{x a t a u} \frac{b Y P_{y}}{X . P x}=1
$$

Dimana $: \mathrm{b}=$ elastisitas

$\mathrm{y}=$ jumlah hasil produksi

Py = harga produksi Y

$\mathrm{X}=$ jumlah faktor produksi $\mathrm{X}$

$\mathrm{Px}=$ harga faktor produksi $\mathrm{X}$

Jika $\left(\mathrm{NPM}_{\mathrm{X}} / \mathrm{Px}\right)>1$; artinya penggunaan input $\mathrm{X}$ belum efisien, untuk mencapai efisien input $\mathrm{X}$ perlu ditambah. Jika $(\mathrm{NPMx} / \mathrm{Px})<1$; artinya penggunaan input $\mathrm{X}$ tidak efisien, untuk menjadi efisien maka penggunaan input $\mathrm{X}$ perlu dikurangi. Efisiensi harga dapat tercapai apabila $\left(\mathrm{NPM}_{\mathrm{xi}} / \mathrm{Px}_{\mathrm{i}}\right)=1$ dan kondisi ini menghendaki NPM sama dengan harga faktor produksi (Soekartawi,1995).

\section{Karakteristik Responden}

\section{HASIL DAN PEMBAHASAN}

Dalam penelitian ini yang menjadi responden adalah petani yang melakukan kegiatan usahatani padi di Desa Simpang Datuk Kecamatan Nipah Pajang Kabupaten Tanjung Jabung Timur sebanyak 39 RTP. Adapun karakteristik responden yang akan dibahas dalam penelitian ini meliputi umur, jumlah tanggungan keluarga, tingkat pendidikan dan lamanya pengalaman berusahatani padi.

Tingkat umur petani sangat terkait dengan tingkat produktivitas tenaga kerja dalam berusahatani. Umur petani di daerah penelitian berkisar antara 29 - 66 tahun, dengan umur rata-rata 45 tahun. Petani didaerah penelitian adalah termasuk usia produktif. Hal ini senada dengan pendapat Suharto (2009), usia kerja produktif berkisar antara14 - 55 tahun, yang pada tingkat umur ini diharapkan seseorang sudah dapat bekerja dan menghasilkan pendapatannya sendiri.

Jumlah anggota yang menjadi tanggungan keluarga petani di daerah penelitian berkisar antara $1-8$ orang, dengan rata-rata jumlah anggota tanggungan keluarga sebanyak 5 orang. Fadholi Hermanto dalam Asmaida (2017), menyatakan jumlah anggota yang menjadi tanggungan keluarga merupakan salah satu faktor yang mempengaruhi keberhasilan usahatani padi, anggota keluarga secara fungsional dapat dimanfaatkan sebagai modal sumberdaya/tenaga kerja dalam usahatani padi, sekaligusjuga sebagai beban tanggungan keluarga yang nantinya akan berpengaruh terhadap ekonomi keluarga petani tersebut.

Tingkat pendidikan responden di daerah penelitian mayoritas berpendidikan SD yaitu sebanyak 25 RTP $(64,10 \%)$. Hal ini menunjukan bahwa tingkat pendidikan petani di daerah penelitian relatif rendah. Rendahnya tingkat pendidikan tentu akan mempengruhi tingkat pengetahuan petani. Hal ini sejalan dengan pendapat Saridewi (2010), yang menyatakan bahwa tingkat pendidikan seseorang dapat mengubah pola pikir, daya penalaran yang lebih baik, sehingga makin lama seseorang mengenyam pendidikan akan semakin rasional.

Lama pengalaman responden dalam berusahatani padi di daerah penelitian berkisar antara 5-34 tahun, dengan rata-rata pengalaman 30 tahun. Hal ini menunjukan bahwa responden memiliki pengalaman yang cukup lama dalam berusahatani padi, dengan demikian diharapkan petani dapat melakukan usahataninya dengan baik dan lebih terampil dalam mengambil keputusan dalam pengelolaan usahatani padi sehingga mampu meningkatkan produksi usahatani padi yang pada akhirnya dapat meningkatkan pendapatan. 
Jurnal Media Agribisnis Vol. 2 No. 2 Tahun 2017 Hal 45 - 59

Media Komunikasi Hasil Penelitian Bidang Ilmu Agribisnis

ISSN print 2548-7027

ISSN online 2541-6898

\section{Analisis Pendapatan Usahatani Padi}

\section{a. Biaya Produksi Usahatani Padi}

Biaya produksi adalah total biaya (total cost) yang digunakan dalam proses produksi yang terdiri dari biaya tetap (fixed cost) dan biaya tidak tetap (varible cost). Rata-rata total biaya yang dikeluarkan responden untuk usahatani padi setiap musim tanam per hektar Rp.8.630.942,- dengan komponen biaya terbesar pada biaya tenaga kerja yaitu Rp.7.236.005,atau $83,84 \%$ dari rata-rata keseluruhan biaya produksi usahatani padi. Untuk lebih jelas dapat dilihat pada Tabel 2.

Tabel 2. Rata-rata Rincian Biaya Produksi Usahatani Padi di Daerah Penelitian Tahun 2017

\begin{tabular}{|c|c|c|c|}
\hline $\mathrm{No}$ & Uraian & Jumlah (Rp/MT/Ha) & Persentase (\%) \\
\hline \multirow[t]{7}{*}{1} & Biaya Tetap (TFC) & 56.402 & 0,65 \\
\hline & a. Parang & 7.884 & 0,09 \\
\hline & b. Ember & 6.253 & 0,07 \\
\hline & c. Handsprayer & 11.353 & 0,13 \\
\hline & d. Arco & 15.196 & 0,18 \\
\hline & e. Cangkul & 2.595 & 0,03 \\
\hline & f. Pajak Lahan & 13.120 & 0,15 \\
\hline \multirow[t]{5}{*}{2} & Biaya Tidak T (TVC) & 8.574 .540 & 99,35 \\
\hline & a. Benih & 428.512 & 4,96 \\
\hline & b. Pupuk & 736.934 & 8,54 \\
\hline & c. Pestisida & 173.089 & 2,01 \\
\hline & d. Tenaga Kerja & 7.236 .005 & 83,84 \\
\hline 3. & Jumlah Biaya Total (TC) & 8.630 .942 & 100 \\
\hline
\end{tabular}

Sumber : Data Primer yang diolah, Tahun 2017

\section{b. Penerimaan Usahatani Padi}

Penerimaan usahatani padi adalah nilai uang yang diterima dari penjualan padi yang merupakan perkalian antara jumlah produksi padi dengan harga jual padi. Ratarata penerimaan Rp.27.507.997,- per musim tanam per hektar, lebih jelas dapat dilihat pada Tabel 3.

Tabel 3. Rata-rata Penerimaan Usahatani Padi Di Daerah Penelitian Tahun 2017

\begin{tabular}{rlcc}
\hline No & \multicolumn{1}{c}{ Uraian } & Satuan & Jumlah \\
\hline 1 & Produksi & $\mathrm{Kg} / \mathrm{MT} / \mathrm{Ha}$ & 3.261 \\
2 & Harga & $\mathrm{Rp} / \mathrm{Kg}$ & 8.436 \\
3 & Penerimaan & $\mathrm{Rp} / \mathrm{MT} / \mathrm{Ha}$ & 27.507 .997 \\
\hline
\end{tabular}

Sumber : Data Primer yang diolah, Tahun 2017

\section{c. Pendapatan Usahatani Padi}

Pendapatan usahatani padi sawah adalah selisih antara penerimaan dengan biaya produksi usahatani padi. Rata-rata pendapatan responden adalah Rp.18.877.055,- per musim tanam per hektar, lebih jelas dapat dilihat pada Tabel 4.

Tabel 4. Rata-rata Pendapatan Usahatani Padi Di Daerah Penelitian Tahun 2017

\begin{tabular}{clc}
\hline No & \multicolumn{1}{c}{ Uraian } & Jumlah $(\mathrm{Rp} / \mathrm{MT} / \mathrm{Ha})$ \\
\hline 1 & Penerimaan & 27.507 .997 \\
2 & Biaya Produksi & 8.630 .942 \\
3 & Pendapatan & 18.877 .055 \\
\hline
\end{tabular}

Sumber : Data Primer yang Diolah, Tahun 2017 
Jurnal Media Agribisnis Vol. 2 No. 2 Tahun 2017 Hal 45 - 59

Media Komunikasi Hasil Penelitian Bidang Ilmu Agribisnis

ISSN print 2548-7027

ISSN online 2541-6898

\section{d. Efisiensi Usaha (RC Ratio)}

Suatu usahatani dikatakan efesien atau tidak efesien ditentukan oleh besar kecilnya hasil yang diperoleh dan besar kecilnya biaya yang dikeluarkan untuk usahatani tersebut. Efesiensi usaha dapat diketahui dengan menghitung return cost ratio (analisis RC), yaitu perbandingan antara total penerimaan dengan total biaya produksi. Berdasarkan data hasil penelitan diperoleh selama satu musim tanam per hektar rata-rata penerimaan responden Rp.27.507.997,- dan rata-rata total biaya Rp.8.630.942,sehingga diperoleh nilai $R C$ Ratio sebesar 3,19. Nilai RC ratio tersebut lebih besar dari 1 , yang menunjukan bahwa rata-rata usahatani padi di daerah penelitian sudah efesien dan menguntungkan. Artinya setiap Rp.1,00 yang dikeluarkan akan menghasilkan penerimaan sebesar Rp.3,19,-.

\section{Analisis Faktor-Faktor Produksi Usahatani Padi}

Faktor-faktor produksi dalam kegiatan usahatani untuk menghasilkan produk berupa gabah (beras) terdiri atas benih, pupuk, pestisida dan tenaga kerja. Dalam pengelolaannya perlu diketahui bahwa penggunaan faktor-faktor produksi ini berpengaruh atau tidak terhadap hasil produksi usahatani padi di daerah penelitian. Untuk mengetahui pengaruh tersebut digunakan teori fungsi produksi Cobb-Douglass dengan menggunakan alat analisis regresi berganda dengan bantuan alat analisis program SPSS, yang sudah di-transformasikan ke dalam bentuk fungsi linier. Sebelum dilakukan estimasi model regresi berganda tersebut, data yang digunakan harus dipastikan terbebas dari penyimpangan asumsi klasik diantaranya uji multikolinearitas, heteroskesdasitas, normalitas dan autokorelasi. Hasil uji asumsi klasik dalam penelitian ini adalah sebagai berikut :

\section{A. Hasil Uji Asumsi Klasik a). Uji Multikolinearitas}

Uji multikolinearitas adalah digunakan untuk mengetahui apakah terjadi hubungan antar variabel independen dengan variabel independen lainnya. Apabila hal ini terjadi, maka terjadi masalah multikolinearitas sebab model regresi yang baik seharusnya tidak terjadi korelasi diantara variabel independennya, hasil uji lebih jelasnya dapat dilihat pada Tabel 5.

Tabel 5. Hasil Uji Multikolinearitas dengan menggunakan Nilai VIF

\begin{tabular}{lccc}
\hline \multicolumn{1}{c}{ Variabel } & Tolerance & Nilai VIF & Keterangan \\
\hline Benih $\left(\mathrm{X}_{1}\right)$ & 0,173 & 5.785 & Tidak terjadi Multikolinearitas \\
Pupuk $\left(\mathrm{X}_{2}\right)$ & 0,247 & 4.051 & Tidak terjadi Multikolinearitas \\
Pestisida $\left(\mathrm{X}_{3}\right)$ & 0,305 & 3.278 & Tidak terjadi Multikolinearitas \\
Tenaga Kerja $\left(\mathrm{X}_{4}\right)$ & 0,108 & 9.242 & Tidak terjadi Multikolinearitas \\
\hline
\end{tabular}

Sumber : Data Primer yang Diolah, Tahun 2017

Berdasarkan hasil analisis data uji multikolinearitas dengan menggunakan nilai VIF dan nilai tolerance menunjukan tidak terjadi multikolinearitas pada model regresi.

\section{b). Uji Heteroskedastisitas}

Uji heteroskedastisitas digunakan untuk menguji apakah dalam suatu model regresi terjadi ketidaksamaan variance dan residual dari satu pengamatan ke pengamatan yang lain. Jika variance dari residual satu pengamatan ke pengamatan lain tetap, maka disebut homoskedastisitas, namun apabila berbeda maka tidak terjadi heteroskedastisitas. 
Jurnal Media Agribisnis Vol. 2 No. 2 Tahun 2017 Hal 45 - 59

Media Komunikasi Hasil Penelitian Bidang Ilmu Agribisnis

ISSN print 2548-7027

ISSN online 2541-6898

Berdasarkan keterangan pada Gambar 1, dapat diketahui bahwa tidak terjadi heteroskedastisitas. Hal ini disebabkan karena tidak ada pola yang jelas serta titik-titik menyebar di atas dan di bawah angka 0 pada sumbu Y, sehingga dapat dikatakan uji heteroskedastisitas terpenuhi.

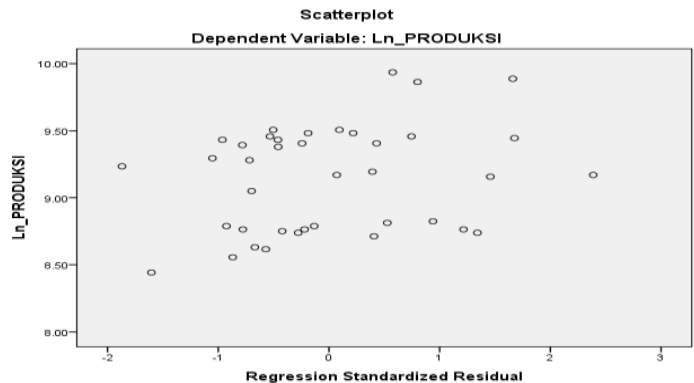

Gambar 1. Grafik Scatterplot Hasil Uji Heteroskedastisitas

\section{c). Uji Normalitas}

Uji asumsi normalitas digunakan untuk menguji apakah dalam suatu model regresi, varibel dependen atau keduanya mempunyai distribusi normal atau mendekati normal (Santoso, 2000). Berdasarkan penjelasan tersebut bahwa Apabila asumsi normalitas tidak terpenuhi maka baik uji $\mathrm{F}$ ataupun uji-t, dan nilai estimasi nilai variabel dependen menjadi tidak valid. Berdasarkan keterangan Gambar 2, bahwa terlihat titiktitik yang menyebar disekitar garis diagonal serta penyebarannya mengikuti garis tersebut. Dari hasil tersebut dapat disimpulkan bahwa model regresi yang digunakan telah memenuhi asumsi normalitas.

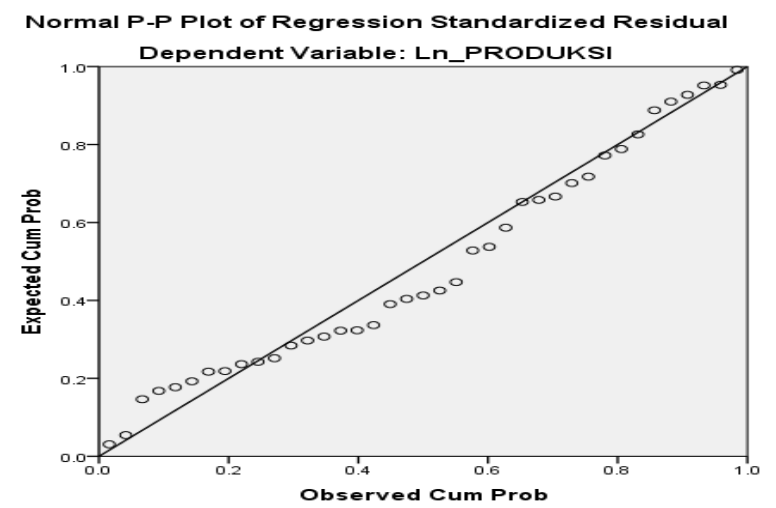

\section{d). Uji Autokorelasi}

Gambar 2. Gambar Grafik Normal P-Plot

Menurut Santoso (2000) bahwa tujuan uji autokorelasi adalah untuk mengetahui apakah dalam suatu model regresi linear ada korelasi antara kesalahan pengganggu dengan kesalahan sebelumnya. Hasil pengujian terhadap model regresi yang dilakukan tidak terdapat autokorelasi, karena nilai DW sebesar 2 lebih besar dari batas atas (du) 1,775 dan kurang dari 4-1,775 (4-du).

\section{B. Pengujian Hipotesis}

Hasil uji asumsi klasik regresi linear berganda untuk mengetahui pengaruh variabel bebas (independen) pada penggunaan input usahatani padi (benih, pupuk, pestisida, dan tenaga kerja) terhadap variabel terikat (dependen) atau hasil produksi padi, dapat dilihat pada Tabel 6 . 
Jurnal Media Agribisnis Vol. 2 No. 2 Tahun 2017 Hal 45 - 59

Media Komunikasi Hasil Penelitian Bidang Ilmu Agribisnis

ISSN print 2548-7027

ISSN online 2541-6898

Tabel 6. Hasil Analisis Regresi Fungsi Produksi Cobb-Douglass Usahatani Padi di Daerah Penelitian Tahun 2017

\begin{tabular}{lccc}
\hline \multicolumn{1}{c}{ Variabel } & Koefisien Regresi & Std. Error & t hitung \\
\hline Konstanta & 3,433 & 0,368 & 9.338 \\
Benih (X1) & 0,383 & 0,124 & 3.104 \\
Pupuk (X2) & 0,534 & 0,082 & 6.543 \\
Pestisida (X3) & 0,005 & 0,050 & 0,105 \\
Tenaga Kerja $(\mathrm{X} 4)$ & 0,141 & 0,116 & 1.214 \\
\hline Adjusted $\mathrm{R}^{2}$ Square $=0,934$ & $\mathrm{t}_{\text {tabel }} \alpha_{0,05}=2,026$ & & \\
$\mathrm{~F}_{\text {Hitung }}=135.926$ & Taraf kepercayaan $95 \%$ & & \\
$\mathrm{~F}_{\text {tabel }} \alpha_{0,05}=2,689$ & & & \\
\hline
\end{tabular}

Sumber : Data Primer yang Diolah, Tahun 2017

Berdasarkan hasil analisis regresi pada Tabel 6 di atas, diperoleh persamaan regresi :

$\operatorname{LnY}=3,433+0,383 \operatorname{LnX}_{1}+0,534 \operatorname{LnX}_{2}+0,005 \operatorname{LnX}_{3}-0,141 \operatorname{LnX}_{4}+e^{u}$

\section{a). Analisis Uji Keragaman (Uji F)}

Analisis uji $\mathrm{F}$ digunakan untuk menguji variabel independen yang terdiri atas benih, pupuk, pestisida, dan tenaga kerja berpengaruh terhadap jumlah produksi usahatani padi di daerah peneitian. Berdasarkan hasil uji $\mathrm{F}$ yang telah dilakukan melalui pengolahan data menggunakan program SPSS, diperoleh nilai $F_{\text {hit }}$ sebesar $135.926>$ nilai $F_{\text {tabel }}:(\alpha=0,05)(d f=4 ; 34)$ sebesar 2,689, artinya bahwa secara bersama-sama dari semua variabel independen (benih, pupuk, pestisida, dan tenaga kerja) berpengaruh terhadap variabel dependen (produksi padi).

\section{b). Analisis Uji Koefisien Determinasi $\left(\mathbf{R}^{2}\right)$}

Uji koefisien determinasi menunjukkan seberapa baik variabel-variabel bebas menjelaskan hasil (multiple correlation coefficient). Dalam penelitian ini, nilai Adjusted $\mathrm{R}^{2}$ Square $=0,934$ atau 93,4\% menunjukkan bahwa kemampuan variabel bebas dalam memberikan informasi untuk menjelaskan keragaman variabel terikat relatif tinggi. Sehingga dapat disimpulkan bahwa variabel bebas (benih, pupuk, pestisida, dan tenaga kerja) memiliki pengaruh yang besar terhadap peningkatan maupun penurunan produksi usahatani padi dan sisanya sebesar $6,6 \%$ tidak dijelaskan oleh model, akan tetapi dijelaskan oleh faktor lain. Apabila dilihat secara keseluruhan bahwa model yang digunakan dalam penelitian ini cukup baik.

\section{c). Analisis Koefisien Regresi (Uji t)}

Dalam persamaan regresi suatu penelitian, nilai koefisien pada masing-masing variabel independen (benih, pupuk, pestisida, dan tenaga kerja) harus melalui pengujian secara satu persatu, hal ini bertujuan untuk mengetahui variabel independen yang mana yang memiliki pengaruh nyata terhadap variabel dependen (produksi padi). Adapun hasil dan pembahasan uji signifikansi akan dijelaskan sebagai berikut :

\section{Benih}

Nilai $t_{\text {hit }}$ pada variabel benih 3,104 > nilai $t_{\text {tabel }} 2,026$, maka secara statistik benih yang digunakan untuk kegiatan usahatani padi berpengaruh nyata terhadap jumlah produksi padi. Nilai koefisien regresi sebesar 0,383 menunjukkan bahwa penambahan jumlah benih sebesar $1 \%$ akan meningkatkan produksi rata-rata sebesar $0,383 \%$, dengan asumsi faktor yang lain dalam keadaan konstan. Semakin besar jumlah yang digunakan maka akan menghasilkan produksi yang semakin tinggi, namun hal ini harus disesuaikan dengan kondisi lahan yang ada juga input usahatani yang digunakan. Salah satu penyebab bahwa benih berpengaruh terhadap jumlah produksi padi disebabkan karena sebagian besar petani responden di daerah penelitian telah menggunakan benih unggul dan mengikuti anjuran pemerintah. 
Jurnal Media Agribisnis Vol. 2 No. 2 Tahun 2017 Hal 45 - 59

Media Komunikasi Hasil Penelitian Bidang Ilmu Agribisnis

ISSN print 2548-7027

ISSN online 2541-6898

\section{Pupuk}

Nilai $t_{\text {hitung }}$ pada variabel pupuk 6,543 > nilai $t_{\text {tabel }}$ sebesar 2,026, maka secara statistik pupuk yang digunakan untuk kegiatan usahatani padi berpengaruh nyata terhadap jumlah produksi padi. Nilai koefisien regresi sebesar 0,534 menunjukkan bahwa penambahan jumlah pupuk sebesar $1 \%$ akan meningkatkan produksi rata-rata sebesar $0,534 \%$, dengan asumsi faktor yang lain dalam keadaan konstan. Semakin besar jumlah pupuk yang digunakan maka akan menghasilkan produksi yang semakin tinggi, namun hal ini harus disesuaikan dengan kondisi lahan yang ada juga input usahatani yang digunakan.

\section{Pestisida}

Nilai $t_{\text {hitung }}$ pada variabel pestisida $0,105<$ nilai $t_{\text {tabel }}$ sebesar 2,026 , maka secara statistik pestisida yang digunakan untuk kegiatan usahatani padi tidak berpengaruh nyata terhadap jumlah produksi padi. Berdasarkan hasil penelitian yang dilakukan, nilai koefisien regresi sebesar 0,005 menunjukkan bahwa peningkatan alokasi pestisida sebesar $1 \%$ akan menaikkan produksi sebesar $0,005 \%$ dengan asumsi faktor yang lain dalam keadaan konstan.

\section{Tenaga Kerja}

Nilai $t_{\text {hitung }}$ pada variabel tenaga kerja $1,214<$ nilai $t_{\text {tabel }}$ sebesar 2,201, maka secara statistik tenaga kerja yang digunakan untuk kegiatan usahatani padi tidak berpengaruh nyata terhadap jumlah produksi padi. Berdasarkan hasi penelitiann, nilai koefisien regresi pada variabel tenaga kerja adalah sebesar 0,141 menunjukkan bahwa peningkatan alokasi tenaga kerja sebesar $1 \%$ akan meninggkatkan produksi padi sebesar $0,141 \%$, dengan asumsi faktor yang lain dalam keadaan konstan.

\section{Analisis Efisiensi Alokatif Penggunaan Faktor-Faktor Produksi}

Efisiensi alokatif dari penggunaan faktor-faktor produksi pada kegiatan usahatani padi dapat diketahui dengan cara menghitung rasio nilai produk marjinal dengan harga masing-masing faktor-faktor produksi per satuannya (NPMx/Px). Berdasarkan hasil analisis regresi terdapat variabel independen yang berpengaruh nyata adalah variabel benih dan pupuk. Variabel pestisida dan tenaga kerja memiliki pangaruh yang tidak nyata, sebab koefisien elastisitasnya sama dengan nol atau mendekati nol. Hasil analisis efisiensi alokatif faktor-faktor produksi tersebut dapat dilihat pada Tabel 7.

Tabel 7. Hasil Analisis Efisiensi Penggunaan Faktor-Faktor Produksi Usahatani Padi Di Daerah Penelitian Tahun 2017

\begin{tabular}{|c|l|c|c|c|c|c|c|c|}
\hline No. & Uraian & $\mathrm{Bi}$ & $\mathrm{Xi}$ & \multicolumn{1}{c|}{ Pxi } & \multicolumn{1}{c|}{ Py } & NPMxi & NPMxi/Pxi & Xi Optimal \\
\hline 1. & Benih & 0,383 & 156 & 8500 & 8436 & $209.557,857$ & 24,65 & 76,912 \\
\hline 2. & Pupuk & 0,534 & 518 & 11500 & 8436 & $87,983,21$ & 7,650 & 7,651 \\
\hline
\end{tabular}

\section{Sumber : Data Primer yang Diolah, Tahun 2017}

Berdasarkan Tabel 7, menunjukkan bahwa hasil analisis efisiensi alokatif penggunaan benih sebesar 24,65 $\mathrm{kg}$ dan penggunaan pupuk sebesar 7,650 kg. Hasil alokasi penggunaan benih dan pupuk tersebut lebih dari 1, sehingga belum efisien secara alokatif. Agar penggunaan benih dan pupuk efisien, maka perlu dilakukan penambahan alokasi benih sebesar 76,912 kg/3ha dan penambahan alokasi pupuk sebesar 7,651 kg/3ha. Berdasarkkan teori fungsi produksi Cobb-Douglas ini memiliki beberapa kelemahan yang menyebabkan nilai elastisitas produksi yang diperoleh negatif atau nilainya terlalu besar atau kecil (Sudarman, 1989). Sehingga penambahan jumlah benih sebesar $76,912 \mathrm{~kg} / 3 \mathrm{ha}$ sangat sulit untuk diaplikasikan di lapang, mengingat anjuran jumlah benih maksimal per hektar lahan sawah adalah $20 \mathrm{~kg} / \mathrm{ha}$ atau $60 \mathrm{~kg} / 3 \mathrm{ha}$ (BB Padi, 2016). Sedangkan hasil analisis efisiensi alokatif penggunaan input pupuk, jumlahnya sudah mendekati optimal atau efesien. 
Jurnal Media Agribisnis Vol. 2 No. 2 Tahun 2017 Hal 45 - 59

Media Komunikasi Hasil Penelitian Bidang Ilmu Agribisnis

ISSN print 2548-7027

ISSN online 2541-6898

\section{KESIMPULAN}

Hasil penelitian menunjukan bahwa di daerah penelitian :

1. Rata-rata per musim tanam per hektar hasil total penerimaan petani padi di Desa Simpang Datuk Kecamatan Nipah Panjang sebesar Rp.27.507.997, total biaya sebesar Rp.8.630.942 dan pendapatan sebesar Rp.18.877.055. Sehingga diperoleh nilai $\mathrm{R} / \mathrm{C}$ rasio sebesar 3,19. Hal ini menunjukkan bahwa rata-rata usahatani padi cukup menguntungkan, karena rata-rata nilai RC rasionya lebih dari 1 . Sehingga setiap Rp.1,00 yang dikeluarkan akan menghasilkan penerimaan sebesar Rp.3,19.

2. Faktor-faktor produksi yang berpengaruh dalam kegiatan usahatani padi di Desa Simpang Datuk Kecamatan Nipah Panjang Kabupaten Tanjung Jabung Timur adalah faktor produksi benih dan pupuk. Hal ini menunjukkan bahwa penambahan jumlah penggunaan benih dan pupuk akan berpengaruh lebih besar terhadap produksi padi. Sedangkan dua faktor produksi lainnya yaitu faktor pestisida dan tenaga kerja tidak berpengaruh.

3. Hasil analisis efisiensi alokatif penggunaan faktor-faktor produksi usahatani padi menunjukkan alokasi penggunaan benih sebesar 24,65 kg dan penggunaan pupuk sebesar 7,650 kg, hasil alokasi penggunaan benih dan pupuk tersebut lebih dari 1, sehingga belum efisien secara alokatif. Agar penggunaan benih usahatani padi efisien, maka perlu dilakukan penambahan alokasi benih sebesar 76,912 kg/3ha dan penambahan alokasi pupuk sebesar 7,651 kg/3ha. Berdasarkkan teori fungsi produksi Cobb-Douglas ini memiliki beberapa kelemahan yang menyebabkan nilai elastisitas produksi yang diperoleh negatif atau nilainya terlalu besar atau kecil (Sudarman, 1989). Sehingga penambahan jumlah benih sebesar $76,912 \mathrm{~kg} / 3$ ha sangat sulit untuk diaplikasikan di lapang, mengingat jumlah benih maksimal per hektar lahan sawah adalah $20 \mathrm{~kg} / \mathrm{ha}$ atau $60 \mathrm{~kg} / 3$ ha (BB Padi, 2016), sedangkan hasil analisis efisiensi alokatif penggunaan input pupuk, jumlah input pupuk tersebut sudah mendekati optimal atau efesien.

\section{DAFTAR PUSTAKA}

Asmaida. 2017. Hubungan Aspek Sosial Dengan Keputusan Nelayan Dalam Pemasaran Hasil Perikanan Tangkap Di Kabupaten Tanjung Jabung Barat. Jurnal Media Agribisnis Vol.2 No. 1. ISSN 2541-6898. Program Studi Agribisnis Fakultas Pertanian. Universitas Batanghari. Jambi.

BP3K Kecamatan Nipah Panjang. 2015. Provinsi Jambi Kecamatan Nipah Panjang Dalam Angka 2015. BPS Provinsi Jambi.

Ghozali, Imam. 2008. Aplikasi Analisis Multivariate Dengan Program SPSS. Undip Press. Semarang.

Gujarati, D. 1997. Ekonometrika Dasar. Jakarta. Penerbit Erlangga. . 2005. Basic Econometric. Diterjemahkan oleh Sumarno Zain. Erlangga. Jakarta.

Husein Umar, 2003. Metode Penelitian. Salemba Empat. Jakarta.

Kadariah, Lien. K., dan Clive. G. 1976. Pengantar Evaluasi Proyek Jilid I. UI-Press, Jakarta.

Santoso,S. 2000. Buku Latihan SPSS Statistik Parametrik. Elex Media Komputindo. Jakarta. 
Jurnal Media Agribisnis Vol. 2 No. 2 Tahun 2017 Hal 45 - 59

Media Komunikasi Hasil Penelitian Bidang Ilmu Agribisnis

ISSN print 2548-7027

ISSN online 2541-6898

Saridewi, T.R. dan Siregar, A. N. 2010. Hubungan antara peran penyuluh dan adopsi teknologi oleh petani terhadap peningkatan produksi di Kabupaten Tasikmalaya. Jurnal Penyuluhan Pertanian Volume 5 No.1 Mei 2010. Diakses 5 Januari 2017.

Silalahi, U. 2010. Metode Penelitian Sosial. PT. Refika Aditama. Bandung

Singarimbun M dan S. Effendi. 1995. Metode Penelitian Survei Edisi kedua. LP3ES, Jakarta.

Soekartawi, 1986. Ilmu Usahatani dan Penelitian Untuk Pengembangan Petani Kecil. Universitas Indonesia Press. Jakarta. 1994. Analisis Usahatani. Jakarta . UI Press

2000. Ilmu Usahatani dan Penelitian Untuk Pengembangan Usahatani Kecil. UI. Press. Jakarta.

2003. Teori Ekonomi Produksi Dengan Pokok Bahasan Analisis Fungsi Cobb-Douglas. PT. Raja Grafindo Persada. Jakarta.

Suharto, Edy. (2009) Pekerja Sosial di Dunia Industri. PT Refika Aditama. Bandung

Tasri E,S, 2007. Metodologi Penelitian Ekonomi dan Bisnis. Bung Hatta University Press, Padang.

Utomo, Yuni Prihadi. 2007. Eksplorasi data dan analisis Regresi dengan SPSS. Muhammadiyah University Press. Surakarta. 